Portland State University

PDXScholar

$5-2-1968$

\title{
The Development of a Clay Body with Compatible Glaze Formulae
}

Nancy Travers

Portland State University

Follow this and additional works at: https://pdxscholar.library.pdx.edu/open_access_etds

Part of the Art Practice Commons, and the Ceramic Arts Commons Let us know how access to this document benefits you.

\section{Recommended Citation}

Travers, Nancy, "The Development of a Clay Body with Compatible Glaze Formulae" (1968). Dissertations and Theses. Paper 428.

https://doi.org/10.15760/etd.428

This Thesis is brought to you for free and open access. It has been accepted for inclusion in Dissertations and Theses by an authorized administrator of PDXScholar. Please contact us if we can make this document more accessible: pdxscholar@pdx.edu. 


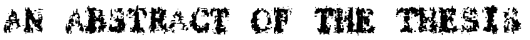

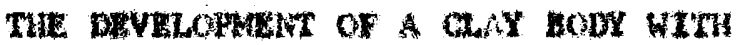

CAPATIRLE GLARE FORUL,AE

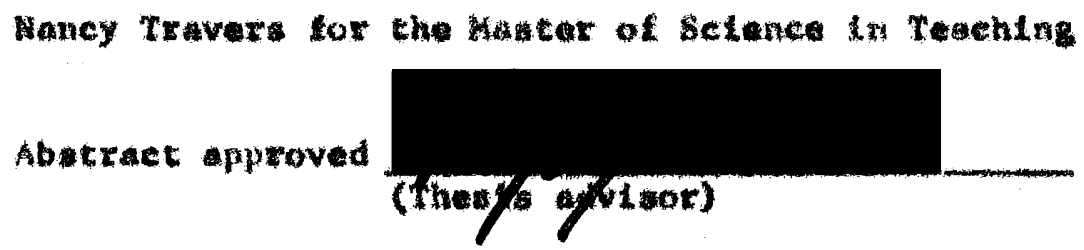

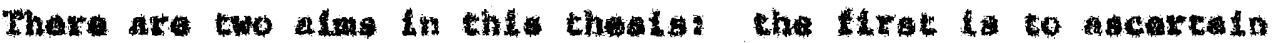
cowethime of the phyoleal and cheateal rogerthes elay and lazea and how to hadile and control then. A project weh a the wevelognert of a clay body and ghas formula arves to lachate the varlous

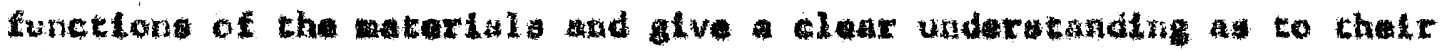

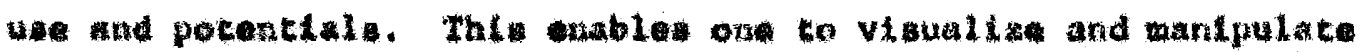

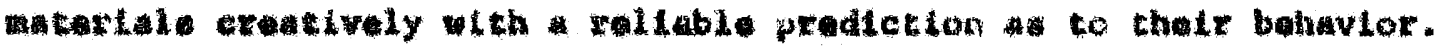

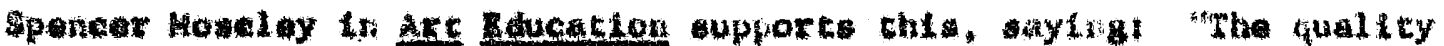

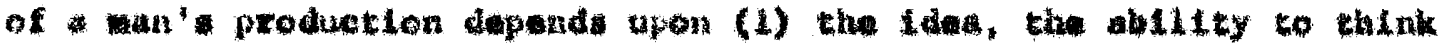

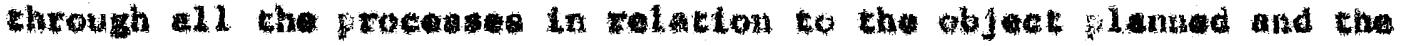

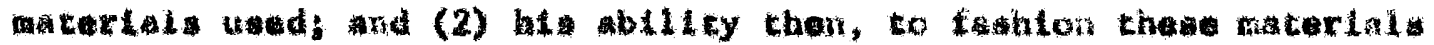
with akin.

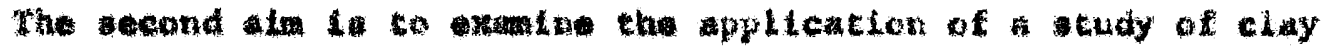

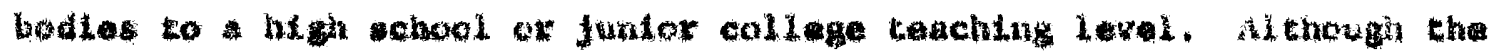

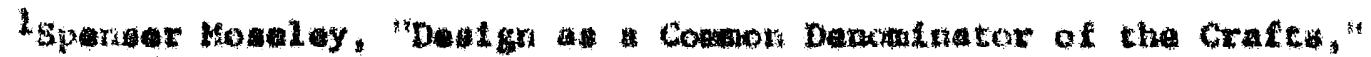
AEt Education XVII (Nov. 1904), 8m13. 


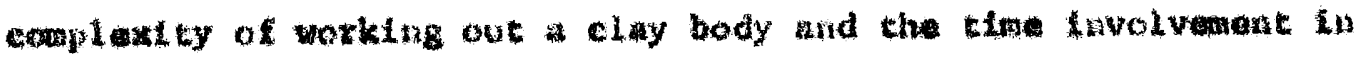
dolne it would not readily lend thomalvan co thesa cuaching levels,

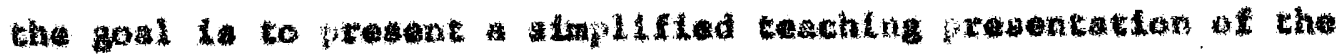

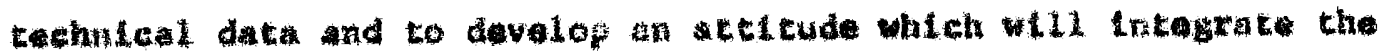
project. 
THE DEVELORMENT OF A CLAY BODX WITH COMPATIBLE GLAZE FOBMULAE

\section{A TuzsIs}

BY

NANCY TRAVERS

PRESENTED TO THE DEPARTMENT OF ART AND THE GRADUATE COUNCIL OE PORTLAND STATE COLLEGE

IN PARTIAL FULEILLMENT OF THE REPUIREMENTS FOR THE DEGREE OF

MASTERS OF SCTENCE IN TEACHLNG June 9, 1968

PORTLAND STATE COLLEGE LIBRARY 
ARPROVED:

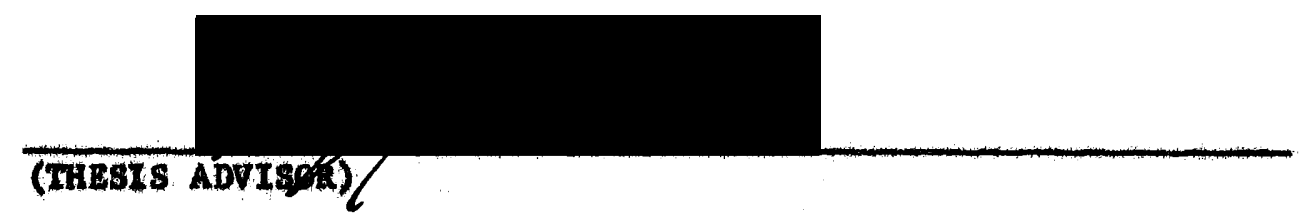

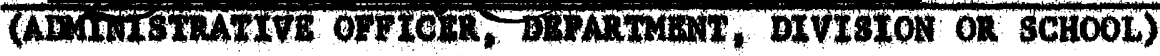

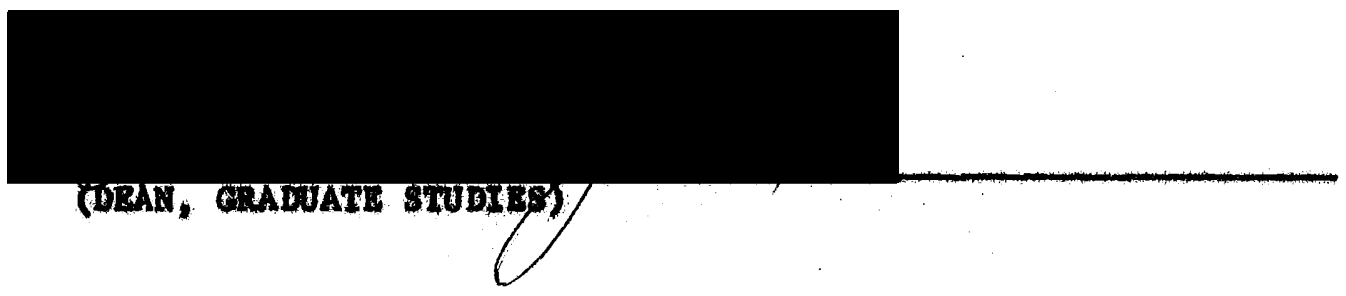




\section{CONTENTS}

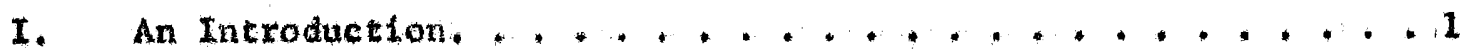

II. Development of a Clay Body , . . , , , , , , ., , 6

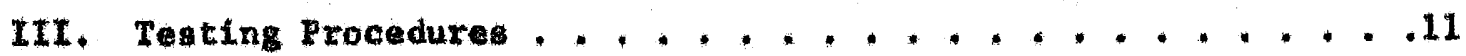

IV. Compatible Glare Forwulae. . . . . , . . , , . . . 18

V. Appifcation to a Teaching situation. . . . . . . . . . 19

VI. Illustrations, ............................22

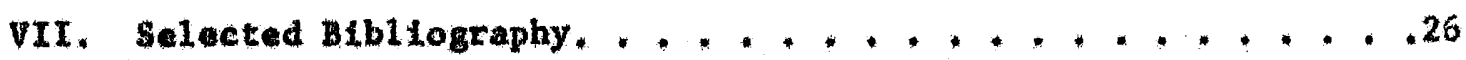


A project such as the development of a clay body must be seen in its broader scope in order to understand its value and purpose. This project is an integral part of a concept which progresses from pottery to crafts, to art education and finally to today's society. If one starts by contemplating today's society and works back it will enable him to understand the total picture.

The Industrial and now the Cybernetics Revolution have confronted man with major changes in his living pattern. Leisure time has increased and the work day has developed into a block of time, which can be devoid of emotional satisfaction. In his job situation he has in many instances a replacement for his muscular activities and less demand on his mental powers. He can eliminate physical labor with the push of a button or can acquire information with a turn of the wrist (TV, radio, hi-fi, or inter-communications systems, etc.). Leisure and working time can easily be spent with a preponderance of passive involvement where all outside stimuli come in and one fails to analyze, observe and outwardly express his emotions and ideas. Outward expression can be called creativity and is vital to man's existence. MoholyNagy says, "To live without this, means emotional starvation just as missing food means starvation to the body."1

Creative activity is the means by which man develops his

${ }^{1}$ Laszlo Moholy-Nagy, V1sion in Motion (New York, 1962), p. 28. 
trituitive learning, aesthetic growth and understanding. Frior to the Industral Revolution, crealivity was a part of everyay existence. At a meter of necesstey the average man had to create his own food, clothes, home furniturs, entercatrment or other living requirenents not provided by technology. Today, man's environment provides less need to create and he seck new avenues to furmish this lack. Evidence of this 1 s the cultural revolution taking place in the United states. And most algnificant is the facrease of people becoming personally involved in the creative fleld through adult education. Here an Increasing number of clases are being opened and the demand is great in the art classes, according to Jerry Healing, Director of Adult Education in Lake Oswego, Oregon.

Art education has two functions. First, the development of crative thinking and, second, the perfection of skills that will give a flum foundation to the cxative endeavor. Creative thinking follows - logteal saquence of thought. It is characterized by (1) preparation, (2) incubation, (3) illumination, and (4) verifleation. Creative thinking can be little exercised, thwarted by emotlonal blocks and difficult for some people. They are fearful of expression, etriving for perfection, a quality of their technologtcal environment and the great ginds and accomplishment that are a part of their everyday lives through mass media. This fear produces a paralysis of creative attempts.

While encouraging creativeness, the teacher must also offer direction in craftamanship and technique. This should safeguard againat a provalifing program whlch over-emphasiges the aceeptability of 
originality and erroneously puts total value on original self expression to the detriment of craftsmanship and a knowledge of design, Art Education has this to say about such a program:

It Io generally felt that verbalization and research stifle creativity. This practice of skills such as calligraphy, perspective, design exercises, and color problems are sacrificed to the stimulation of the imagination through 'motivations,' The emphasis on the irrational and the absurd is often reflected in these axerclses emulating the profesatomal 'avant gard.' Craftgmanship and technique are considered incidental to the overwhelming acceptance of originalicy a criterla of a work of art.2

The problems set up in an art education course should act as self-development through self-effort. Each problem serves as an exercise towards the solution at hand or for problem in general. The process of creation, followed by the act of doing, must be an outgrowth of one's own expertences. Each deaign becomes an expertment, wach line problen to solve. All the universal laws are in opertation and the knowledge gathergd helghtens intultion. This unconselous knowledge becomes an motional or spiritual element os opposed to the moxe intellectual laws of mathematics and geometry governing design. Intuition gives the aolution for what feel is best for a problem, art of otherwise. With this development follows developtrent of aesthetics. ThIs is an lnotinctive tendency to achieve beauty. ${ }^{3}$

The naxt responstbility of an art program is the development of skilla and technical data. Thio information is of a conerete nature ${ }^{2}$ Ida Shimans, "Cultural Explostons," Art Education XIX (June, 1966), 3-8.

${ }^{3}$ see Adol fo Best-Maugard, A Mathod of dreative DesLga (Wow York, 1949), P. 124 , 
and is often sought out by unimaginative teachers and tudents as a safe haven. This is especially true in the how-to-do-it courses where students are encouraged to palnt from photographs, copy patterns, or pour $11 p$ into molds. The emphasis is on accuracy of technique with the Imagination fitting Into a preconceived plan. Without the creative thought processes, the skil1s and technical information become mechanical operations devold of artistic expression. Ideally speaking, the creative and technical should be interrelated wth one oupporting the other and direction given to both. Technical data is essentlal to the craftsman in the preparatory phase of his creative thinking. Here, the development of a clay formula fits into the seheme. By leolating the components so that one can experience systematic unfolding of the functions, the potter achieves a cleax and thorough understanding of his materials. This is a prexcquisite to the invention of the new effects and combinations. One will find a relationghip between productive creative thinking and knowledge or past experience. The croative spaxk can at times seen to come from nowhere, but in actuality it is synthesized information which has becone part of the unconscious. This unconscious thinking is a result of extenaive preparation. 4

In applying the testing procedures which follow, the teacher must keep in mind the relationships of this project to the over-all goals of Art Bducation. There is great danger of letting a project such as this become an end in 1 trelf because it is a safe activity in a

${ }^{4}$ see Catherine Patrick, What is Creative Thinking? (New York, 1955). 
fleld which should always be exploring, observing and pushing towards the new. 
The clay used for the project is mined in Abtoria, Oregon, sold and distributed by Maynard ChrLtiansen, 3390 s. Mapleton Drive, Lake Oswego, Oregon and has the trade name of Clatsop Clay. It can be purchased in lther a dry powder form or pugged in plastic bags. This particular elay was chosen for the project because it is avallabla locally and is in pure form from the mine. This aliminated the problem of digging one's own clay, an activity which did not heve value at this time.

Several reports had previously been done on the clay. These were by geologlets and have 1ittle value to the potter other than to serve as arting point or to indicate complete rejection as a potter's clay, The report from the state Department of Geology and Mineral Industry provided the most ignificant information. The information was as follows:

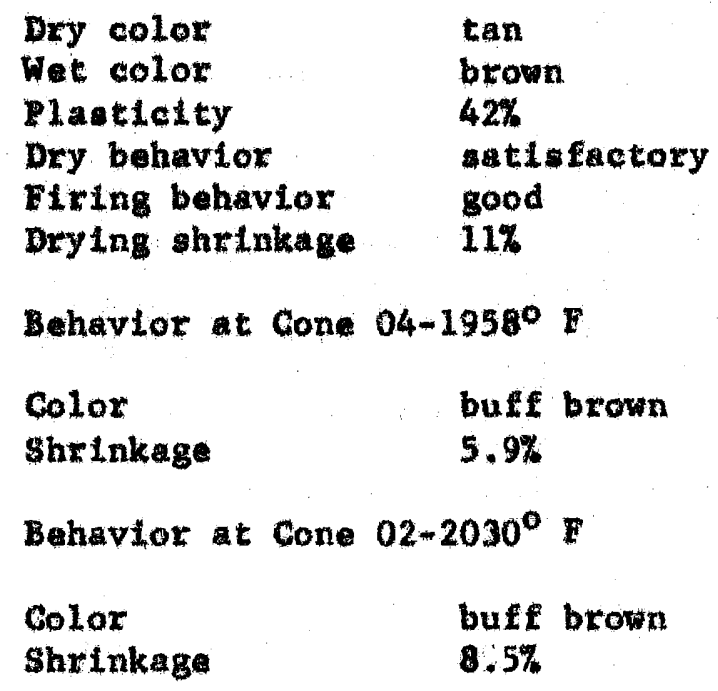

(Shrinkage at Cone 04 and 02 is in addition to the 
dxy shrinkage.)

Clay is by chantcal analysis made up of alumina, silica and water. In actuality 1 t 18 more complex and contains metal oxldes and impurities. Dug directy from the ground, it can rarely be used by the potter without further adjustments to meet his purposes; hence, we have a clay formula.

The potter uses clay for various purpoes and varies the formula accordingly. A throving clay may be different from one designed for large hand-bullt pottery or thet used for alay sculptures. Each formula has three diviston of materials and these are adjusted according to the needs, The three divisions are plasties, nonplastics and fluxes.

plastled are the materials that add plastetcy to the body. Plasticlty means the ability of the clay to "stretch" and this varies from clay to clay. This is the result of the physteal coraposition of clay, which is made up of plate-11ke particles that silde one agalnst the other. The finer the particles, the more plastic the clay, since there is more surface area to slide. Fine particle clays ara earthenware, ball clay and bentonite. clays not in this category need the addition of a more plabtic clay for workab111ty. Clay which 19 very plastic causes trouble in drying, as the particles are so fine and close together that the water cannot escape from the interior. Therefore, uneven drying and warping result. This requires a nonplastic for correction.

Non-plasties are materials with little shrinkage in themselves. They allow the clay to dry safely whout undue warplng and cracking. 
These materials leave open spaces between the clay which allow for more even evaporation and help to reduce warplng. Non-plasties al oo reduce total hrinkage of the clay body.

Suttable non-plastic materials are flint, grog, gand, firo clay and kaolin. These materials all react on the clay body in another way and this must be considered, Flint, fire clay, kaolin, and sand are refractory and ratse the fixing temperature. sand is silica or flint but has a larger particle gize wheh may be desirable In certain steuations. Flint should b. 1 imited to 15 per cent but less than 10 per cent gives diffeulty in fitting the glage. Grog is fired clay ground to given partiele size. The particle lze and type of clay used w11 vary the enount of reaction within the clay body. A coarse partcle, high fire grog will raact leas in a toneware body than ane low flre grog. Non-plagteo should not exceed 25 per cent: of the total material.

Tluxes make up the third category. These matertal atd in lowerting the melting polnt of the clay body. This is necessary because clay is composed primarily of ailica, with a melting polnt of $3100^{\circ} \mathrm{F}$. Fluxe lower this tempexature to the requirents of a stoneware body, ranglng from $2250-2400^{\circ} \mathrm{F}$. Feldspar is the chief flux, Coloring oxides weh iron and manganese are fluxes but ustally do not become critical. If, however, one is having difficulty in reaching the desired firing temperature becase of a Low vitrification point of the clay as was the case with the clatsop Clay, then any additional fluxing materials can become important. Fluxes affect vitxifleation of the clay body and absequently decrease 
the absorption. Vitrification is a hardening, tightening and ultimataly the glassiness of the clay. A completely vitrified body would be glass-like, very denge and with no absorption. The potter tops short of this state in his firing and afms at a sonaware body with 1-6 per cent absorption. One can adjust the c1ay body to obtain this point by adding tlux or refractory materfal for adjustment of the vitrification point.

To clarify the above inforation, the following chart will be helpful. It Indicates the area of correction, materials whleh bring about this correction and disadvantages of these materials on the clay body if used to excess. 


\begin{tabular}{|c|c|c|}
\hline AREA OF CORRECTION & MATERIALS & DISADVANTAGES \\
\hline WORKABILITY & $\begin{array}{l}\text { PLASTICS } \\
\text { ball clay } \\
\text { plastic fire clay } \\
\text { bentonite }\end{array}$ & $\begin{array}{l}\text { causes cracking and } \\
\text { warping }\end{array}$ \\
\hline $\begin{array}{l}\text { DRYING } \\
\text { WARPING }\end{array}$ & $\begin{array}{l}\text { NON-PLASTICS } \\
\text { grog } \\
\text { fire clay } \\
\text { sand } \\
\text { flint } \\
\text { kaolin }\end{array}$ & $\begin{array}{l}\text { all materials are refractory } \\
\text { with the exception of } \\
\text { grog } \\
\text { flint and sand in excess } \\
\text { cause dunting }\end{array}$ \\
\hline $\begin{array}{l}\text { VITRIFICATION } \\
\text { ABSORPTION }\end{array}$ & $\begin{array}{l}\text { FLUXES } \\
\text { feldspars } \\
\text { earthenware clay } \\
\text { metal oxides } \\
\text { talc } \\
\text { dolomite }\end{array}$ & $\begin{array}{l}\text { feldspar, tale and dolomite } \\
\text { are non-plastic } \\
\text { used in excess cause } \\
\text { slumping }\end{array}$ \\
\hline
\end{tabular}




\section{TESTING PROCBDURES}

Firot, test the baste clay to be waed in the fomula. This will give ore an lded of its characteriotec and where corrections are nemded. Frepare guall anount of clay (ball with $6^{\prime \prime}$ dimeter) and ran the following test, leaving in the dry state until after the flrst teat.

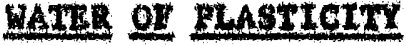

This test Indicates the plastelty of the clay. A clay will Ideally absorb betwean 25-30 per cent vater. Any mount above or balow thit range la likely to be $\mathrm{sign}$ of future problems. Use the collowing formula for this culculation:

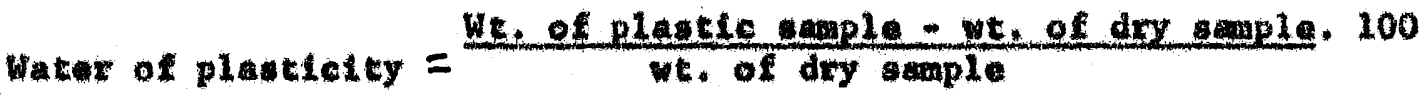
Womserura

Throw a small pot wth the clay. Make a sape that is pulled outward. A good clay bould antliever about 6" beyond the base without cracking along the odge. If the olay 1 s too plaste it will be stieky and hard to handle. For more accurate tont, let the clay age a minimus of one veak.

\section{SHBIULACE}

Draw a Itne of $10 \mathrm{~cm}$, on bar of elay and mark the firing temperature on the bar, After firlng, weasure the ine and the decrease In the measureant of the 11ne will be the pereantage of ahrinkage.

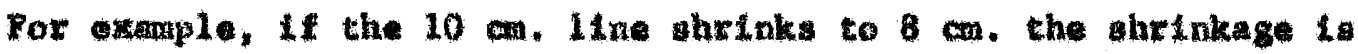
20 per cent. 
DaxtNG

Throw large and elat pleces, letting them dry at room tomperature. Cracks will occur hortzontally and vertically if there to an Inadequate anount of non-plastie present in the elay body. SUMP 20

Make a bax of clay, $10^{\prime \prime}$ by 1 " by " support thita bax in the

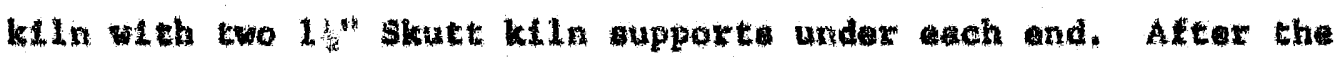
f1Fing, wote the amount of saging between each support. Record the

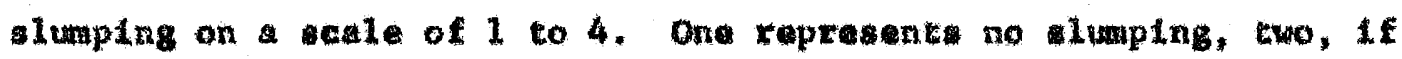
there 19 " ilumplag from the horizontal, chree, if there io $I^{\prime \prime}$ and four, if thare is 1:"

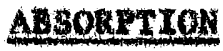

After the clay bax used for the shrinkage test has beon fired,

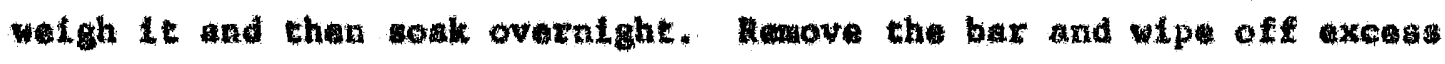
water. Walgh agaln and une the following fortaulat

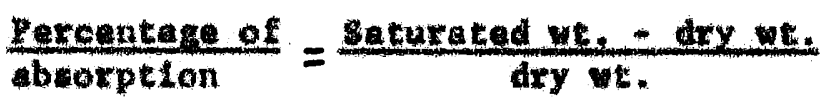
DOWRAS

This la verteal cracking whet takes place in the cooltag of the giase flre. It can be caused by an excens of flitt, ususily over 25 per cent of by cooling the kiln too fats. COLOR

Note the color fter the gla aring.

Record the resulta on a chart set up as follows which wil hereafter be retexrad to as the clay Tat chart. The firet colum 1ndicates the tegt to be performed. The second columing gives the 
Iimits for each test within which the Cone 6 and 10 clay formula must fal1. The third column glves the results of the tests on 100 per cent clatsop clay. The additional columns leave spaces for the recording of any further results as the clay formula is developed. The two final formulae are recorded in these spaces: 


\section{CLAY TEST CHART}

\begin{tabular}{|c|c|c|c|c|}
\hline TESTS & $\begin{array}{l}\text { LIMITS OF } \\
\text { MATERIALS }\end{array}$ & $\begin{array}{l}\text { CLATSOP } \\
100 \%\end{array}$ & CONE 6 BODY & CONE 10 BODY \\
\hline $\begin{array}{l}\text { WATER OF } \\
\text { PLASTICITY }\end{array}$ & $25-30 \%$ & $30 \%$ & $25 \%$ & $23 \%$ \\
\hline WORKABILITY & $\begin{array}{l}\text { Plasticity } \\
\text { which varies } \\
\text { with purpose }\end{array}$ & poor & good & good \\
\hline SHRINRAGE & $10-25 \%$ & $20 \%$ & $18 \%$ & $15 \%$ \\
\hline DRYING & $\begin{array}{l}\text { satisfactory } \\
\text { at room tem- } \\
\text { perature }\end{array}$ & poor & good & good \\
\hline SLUMPING & $1-2$ & 3 & 2 & 2 \\
\hline ABSORPTION & $1-6 \%$ & $0 \%$ & $5 \%$ & $2 \%$ \\
\hline COLOR & - & $\begin{array}{c}\text { dark brown } \\
\text { glassy }\end{array}$ & $\begin{array}{l}\text { orange } \\
\text { brown }\end{array}$ & warm brown \\
\hline DUNTING & none & none & none & none \\
\hline
\end{tabular}


After the characteristics of the primary clay have been determined, isolate each part that needs correction. Start with workability. This involves its performance as a throwing clay, or sculpture clay and the required plasticity directly affects the drying. If the clay is too plastic, add a non-plastic. If it is not plastic enough, add a more plastic clay such as bentonite or ball clay. Start by using a 75 per cent total clay proportion with 25 per cent left for the fluxes and non-plastics. The clatsop Clay is not plastic enough so a ball clay was added In increasing proportions, Measure out the amounts by parts rather than weight. This makes it easy to vary the size of the sample prepared. Set up a chart as follows to record the results.

\begin{tabular}{|l|c|c|c|c|}
\hline \multicolumn{1}{|c|}{ MATERIALS } & TEST 1 & TEST 2 & TEST 3 & TEST 4 \\
\hline CLATSOP CLAY & 70 & 65 & 60 & \\
\hline BALL CLAY & 5 & 10 & 15 & \\
\hline
\end{tabular}

RESULTS

\begin{tabular}{|l|l|l|l|l|}
\hline PLASTICITY & poor & good & good & \\
\hline DRYING & poor & poor & poor & \\
\hline
\end{tabular}

Tests 2 and 3 were satisfactory. Therefore, using Test 2 set it up in the Clay Testing Chart to determine what the new material has done to the original calculations and where further corrections need to 
be made.

After the workability is adjusted, then work to control the drying. This is corrected by adding a non-plastic. Throw objects with large, flat bottoms. This shape will crack first, if the drying properties are not correct. Too much non-plastic material will cause the pot to simply fall apart because it decreases the dry strength. This fault can be mistaken for cracking, Record the new addition of non-plastic materials on a chart like the previous one and hold the plastic materials constant and vary the non-plastics.

\begin{tabular}{|c|c|c|c|c|c|}
\hline MATERIALS & TEST 1 & TEST 2 & TEST 3 & TEST 4 & TEST 5 \\
\hline CLATSOP GLAY & 65 & 65 & 65 & 65 & 65 \\
\hline BALL CLAY & 10 & 10 & 10 & 10 & 10 \\
\hline FLINT & 20 & 15 & 10 & 10 & 10 \\
\hline FELDSPAR (KINGMAN) & 5 & 10 & 10 & 5 & 5 \\
\hline SAND & & & & 5 & \\
\hline GROG & & & & & 5 \\
\hline FIRE CLAY & & & 5 & 5 & 5 \\
\hline
\end{tabular}

RESULTS

\begin{tabular}{|l|l|l|l|l|l|}
\hline PLASTICITY & poor & poor & good & good & poor \\
\hline DRYING & good & good & good & good & good \\
\hline OTHER & & & & & $\begin{array}{l}\text { cuts } \\
\text { dry } \\
\text { strength }\end{array}$ \\
\hline
\end{tabular}


Test 4 turned out to be satisfactory so 1 t whould be retested according to the Clay Test Chart.

The results from the clay Test Chart on Test 4 turned out favorably with the exception of ita plasticity. It could be a 1ittle more plastic. It was also slightly glassy. These minor changes ware corrected without testing. A refractory, plastic fire clay, replaced the ball clay.

The final clay body which was worked out with Clatsop Clay has two formulae. One 1 designed fox Cone 10 which is the temperature comonly used with fuel-burning kilns. The second is a clay body for an lectric kiln which is usually taken to Cone 6 ,

CONE 6 BODX

MATERIALS

Clatsop Clay

Ball clay

KIngman feldspar

Ire clay
CONE 10 BODY

PARTS MATERIALS

Clatsop Clay

sutter clay.

KLngman feldspar

Filnt

Fine and
RARTS

65

15

5

10

5

RESULTS OF CLAX TEST CHART ON THE CLAY FORMULAR

TEST

CONE 6 BODY

CONE $10 \mathrm{BODX}$

Water of plasticity

Workability

Shrinkage

Drying

slumping

$25 \%$

good

$16 \%$

good

2

Absorption

Color

Dunting

$5 \%$

warm orenge

none

$23 \%$

good

$15 \%$

good

2

$2 \%$

warm brown

none 
The following basic glaze recipes were found to be satisfactory with the clay bodles.

GLAZES FOR COWE 6 CLAY BODY

Glossy glaze

Glossy glaza

Matt glaze

Col emanite

Kaolin

55

Colemanite

20

Fint

37

Zne oxtde

Whiting

Kingman spar

Fint

Bartum carbonate

Ball elay

44

24

6

1

GLAZES FOR CONE 10 GLAY BODY

\begin{tabular}{|c|c|c|c|c|}
\hline Glossy glaze & & Matt glaze & & Matt glaze \\
\hline $\begin{array}{l}\text { Kingman feldepar } \\
\text { Koolin } \\
\text { Flint } \\
\text { Whiting } \\
\text { Colemantte } \\
\text { Doldmanite }\end{array}$ & $\begin{array}{r}42.1 \\
1.8 \\
27.2 \\
2.6 \\
8.8 \\
8.8\end{array}$ & $\begin{array}{l}\text { Nepheline oymente } \\
\text { Bariu carbonate } \\
\text { Ball clay } \\
\text { Wlint } \\
\text { Bentonit } \\
\text { Magnestu carbonate }\end{array}$ & $\begin{array}{l}56.5 \\
26 \\
7.5 \\
7.5 \\
10.6\end{array}$ & $\begin{array}{l}\text { Kingman spax } \\
\text { Colemanite } \\
\text { Dolomite } \\
\text { EPK } \\
\text { Filnt } \\
\text { Talc }\end{array}$ \\
\hline
\end{tabular}


The struggle between the creative process and technique is ever present in teaching art. The two are interrelated and support one another but as previously aentloned each can be taught to the excluston of the other. It can al so happen that both are emphasized but the corralation between the two is left vague. It is therefore important that the teacher directs the student towards an underatanding of the relationghip between the two.

The creative process is characterized in four stager. These are preparation, incubation, 11 lumination and verification, 5 in the preparation phase one finds out what the problem ia, he gathers information which is ther past of acquired knowledge and he probes unknown areas, explores and develop his sensttivities to all things which contribute to his problem oolving. It is a time when he keeps an open mind to possibilitiea. It is also a time when he learns to hold back any judgment towards solution so that he ean absorb these possibillties. Those who attempt to evaluate as they create find it extremely difficult if not imposstble to develop new ldeas. The student w111 also experience and learn to accept the uncomfortable feelings that accompany this lack of solution. The lucubation period Is a peculiar stage. It is the Interval between the preparation and the time when an idea can seem to cone from nowhere. This period onds

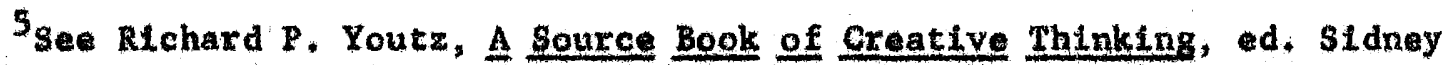
J. Parnes and Harold F, Harding (Nev York, 1962), p. 194. 
when solution is found and all parts seem to fall into place. This is called lliumination. Vertication is the teating or trying out of the solution.

Technical knowledge, such as clay mankulation, glazing, firing, etc. must be acquired as a part of one's preparation for creative endeavor. It should become Intultive knowledge so that it does not block the path of innovation. If it does not become so then it becomes an end in ttgelf. It should be a tochnical means to a creative end.

In applying the study of clay to the classroom, the teachar can give direction to the total concept of creativity but the students" Interesto w11 11e in different areas of this process. This will vary wh theix own growth and motivation. Some will be interested in the digging of clay, others in the testing, some in the expressive use of the clay. These interests should be developed and encouxaged by the teacher with benefit to both the Individual and the rest of the class. This gives ach atudent a spectal place in the classroom through his unique interest.

Also, by having a pergonal knowledge of clay, the teacher is prepared to develop the awareness of the student, Inppire his further exploration and direct him towards self-discovery. In essence, the teacher is ready to encourage when apank appears.

This briags us back to our present-day society which is now out of the Industrial Revolution and 20 to 30 year into the Cybernetics era. It 1 a time of continual change for which we nust be prepared, Our schools and universities are designed to meet the needs of the 
Industrial aga. People can no longer be expected to spend more and more time in school absorbing vast amounts of knowledge. Instead, we must learn to develop creativity and enlarge the capactity of each Individual, As Bechert polnts out,

i. belleve the best way to to this is to change our educational process from being discipline-orlented to being problem-oriented to sot up educational systems which w11 force people to face all the Implications of ach problem and to evaluate the Individual's potenchal in terms of his ablitty to percelve new interconnections between aspects of the problen. 6

${ }^{6}$ Charles R. Dechert, The Social Impact of Cybernetics (London, 1966). 
ILLUSTRATIONS 

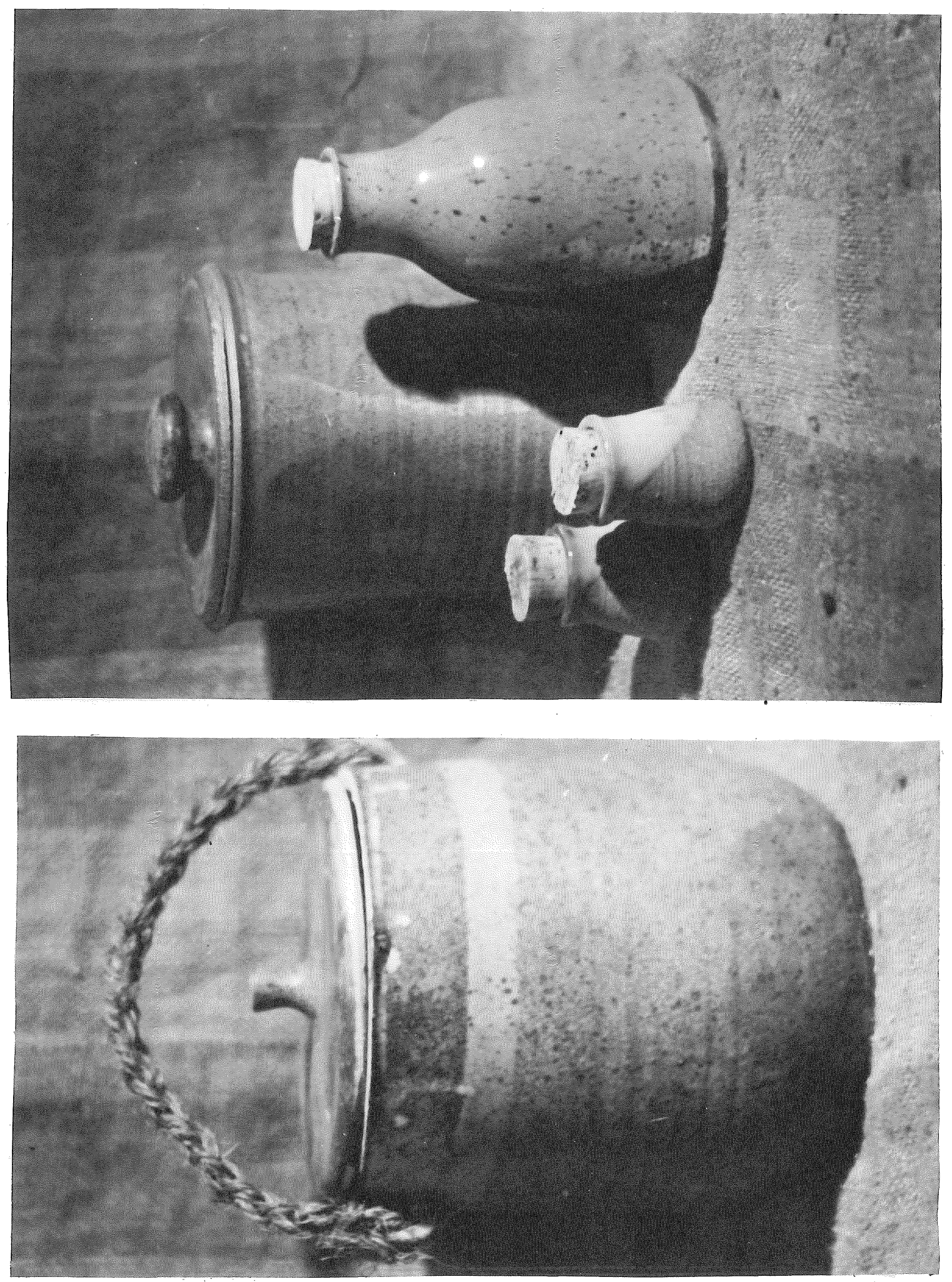

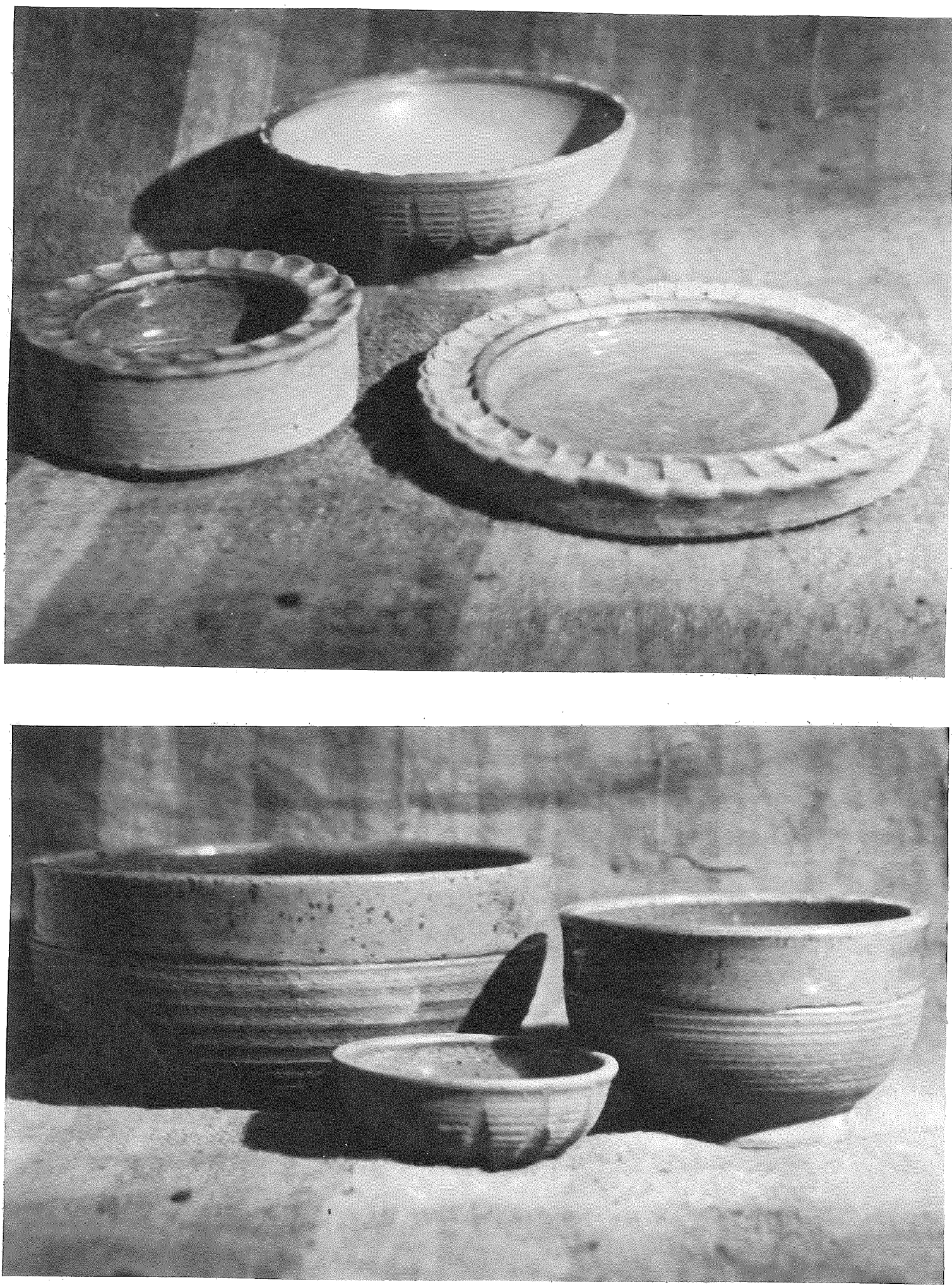

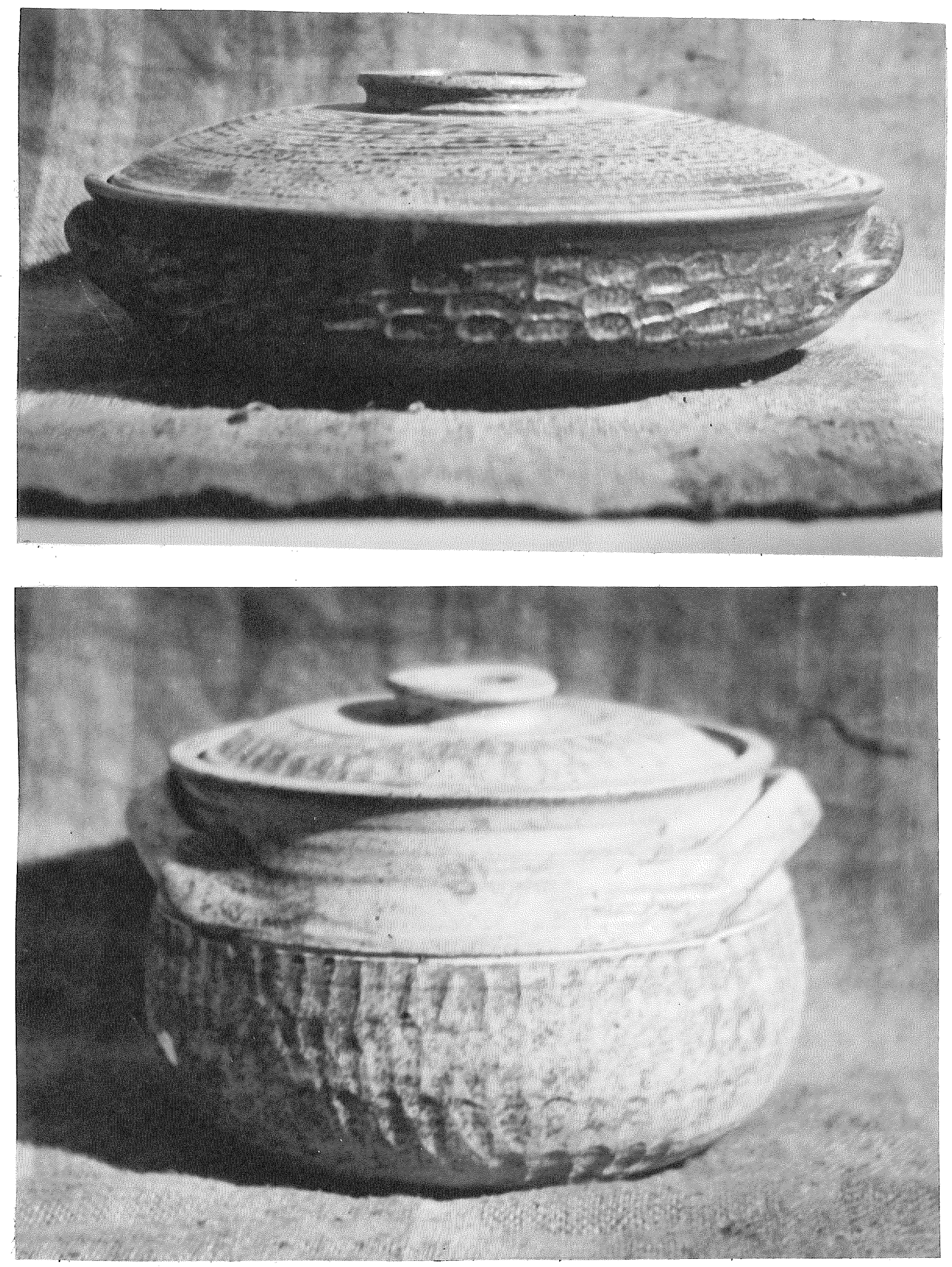


\section{A SELTCTLD BIBLIOGRAPHY}

Andrews, Michael F., ed. Creativity and Psychological Health. U. s., 1961.

Best-Maugard, Ado1fo. A Method of Cxeative Design. New York, 1949.

Dechert, Charles R. The Social Impaet of Cybernetics. London, 1966.

Moholy-Magy, Laszio. Y1aion in MotLon. New York, 1962,

Moseley, Spencer. "Design as a Comon Denominator of the Crafta," Att Education (Nov. 1964), 8-13.

Neloon, Glenn C. Ceramies. New York, 1960.

Norton, George. Elements of Cerantes. Mass, 1952.

Parnea, Sidney J. and Harding, Harold T. A Source Book of Greative Ihinking. New York, 1962.

Patrlck, Catherine, What 18 Creative ThInking? New York, 1955.

Rhodes, Daniel. Clay and Glazer for the Potter. Wew York, 1957. - Stoneware and Porcelain. Rhil, , 1966.

Shimans, Ida, "Cul tural Explosion," Art Education (June, 1966), 3-8.

Wefner, Norbert. The Human Use of Fuman Beings, Cybernetics and Society, Botton, 1954. 